\title{
Synthesis, spectral characterization and antibacterial studies of palladium(II) complexes of heterocyclic thiones
}

\author{
Syed Ahmed Tirmizi ${ }^{\text {a }}$, Shafqat Nadeem ${ }^{\mathrm{a}}$, Abdul Hameed ${ }^{\mathrm{b}}$, \\ Muhammad Hamid Sarwar Wattoo ${ }^{a}$, Aneela Anwar ${ }^{c}$, Zameer Ahmed Ansari ${ }^{c}$ and \\ Saeed Ahmad ${ }^{\mathrm{c}, *}$ \\ ${ }^{a}$ Department of Chemistry, Quaid-i-Azam University, Islamabad, Pakistan \\ ${ }^{\mathrm{b}}$ Microbiology Research Laboratory, Department of Biological Sciences, Quaid-i-Azam University, \\ Islamabad, Pakistan \\ ${ }^{\mathrm{c}}$ Department of Chemistry, University of Engineering and Technology, Lahore, Pakistan
}

\begin{abstract}
Reactions of $\mathrm{K}_{2}\left[\mathrm{PdCl}_{4}\right]$ with heterocyclic thiones in molar ratios of 1:2 and 1:4 in water-methanol medium yielded the palladium(II) complexes with the general formula of either $\left[\mathrm{Pd}(\mathrm{L}) \mathrm{Cl}_{2}\right],\left[\mathrm{Pd}(\mathrm{L})_{2}\right] \mathrm{Cl}_{2}$ or $\left[\mathrm{Pd}(\mathrm{L})_{4}\right] \mathrm{Cl}_{2}$ where $\mathrm{L}=$ Imidazolidine-2-thione (Imt), 2-Mercaptopyridine (Mpy), 2-Mercaptopyrimidine (Mpm), 6-Mercaptopurine (6-Mp) and Thionicotinamide (Tna). The complexes were characterized by elemental analysis and spectroscopic (IR, ${ }^{1} \mathrm{H}$ and ${ }^{13} \mathrm{C}$ NMR) methods. An upfield shift in the $>\mathrm{C}=\mathrm{S}$ resonance of thiones in ${ }^{13} \mathrm{C}$ NMR and downfield shift in $\mathrm{N}-\mathrm{H}$ or aromatic proton resonances in ${ }^{1}$ H NMR are consistent with the sulfur coordination to palladium(II). The complexes were screened for antibacterial activity, and the results showed that the complexes exhibited moderate activities as compared to that of a standard drug.
\end{abstract}

Keywords: Palladium(II), thiones, NMR spectroscopy, antibacterial activity

\section{Introduction}

Heterocyclic thiones are among the ligand systems used to mimic bio-relevant metal-sulfur interactions and therefore, the complexes of heterocyclic thiones such as imidazolidine-2-thione (Imt), diazinane-2-thione (Diaz) and their derivatives with transition metals are of significant interest from bioinorganic chemistry point of view [1-10]. 6-Mercaptopurine and its riboside are anticancer metabolites and their complexes of $\mathrm{Pd}(\mathrm{II})$ and $\mathrm{Pt}(\mathrm{II})$ are known to exhibit antitumor activity [11-13]. In view of this importance, several complexes of thiones with $\mathrm{Cu}(\mathrm{I})$ [14-17], $\mathrm{Ag}(\mathrm{I})$ [18-24], $\mathrm{Au}(\mathrm{I})$ [25-27], $\mathrm{Mo}(\mathrm{II})$ [28], Pd(II) [29-34], Zn(II) [35-39], Cd(II) [39-45] and $\mathrm{Hg}$ (II) [46-50] have been widely studied. We have been interested in the spectral and structural chemistry of several metal ions with thiones in order to study their binding modes and to provide useful models for metalloproteins [16-20,26,27,33,34,41]. As

\footnotetext{
* Corresponding author: Saeed Ahmad, Department of Chemistry, University of Engineering and Technology, Lahore 54890, Pakistan. E-mail: saeed_a786@hotmail.com.
} 
<smiles>S=C1NCCN1</smiles>

Imidazolidine-2-thione<smiles>S=c1cccc[nH]1</smiles>

Mercaptopyridine

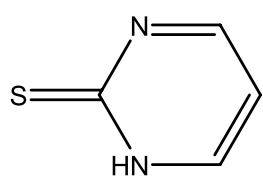

Mercaptopyrimidine<smiles>S=c1[nH]cnc2[nH]cnc12</smiles>

6-Mercaptopurine

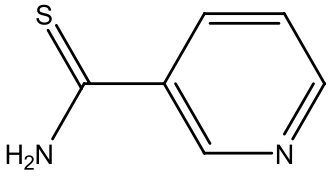

Thionicotinamide

Scheme 1. Structures of the ligands used in the study.

a part of our continuous interest in the structural chemistry of metal-sulfur interactions, we report here the synthesis of palladium(II) complexes with a number of heterocyclic thiones and their characterization by IR, ${ }^{1} \mathrm{H}$ and ${ }^{13} \mathrm{C}$ NMR spectroscopy. We have also investigated the antibacterial activities of these complexes, which in some cases are significant compared to that of a standard drug. The knowledge of coordination behavior of heterocyclic thiones towards palladium(II) would be useful to understand the interactions of heavy metals to nucleotides and related compounds, which may have antitumor activity. The structures of the ligands used in this study are shown in Scheme 1.

\section{Experimental procedure}

\subsection{Materials}

Palladium(II) chloride was purchased from Degussa AG 40474, Düsseldorf, Germany. 2-Mercaptopyridine (Mpy), 2-Mercaptopyrimidine (Mpm), 6-Mercaptopurine monohydrate (6-Mp) and Thionicotinamide (Tna) were purchased from ACROS Organics, USA. Nutrient agar was purchase from OXOID, England. Imidazolidine-2-thione (Imt) was prepared according to the published procedure [26].

\subsection{Synthesis of the complexes}

The potassium tetrachloropalladate(II) was prepared as described in the literature; by the reaction palladium chloride with an excess of potassium chloride [34]. The complexes were prepared by adding 2 and 4 equivalents of heterocyclic thiones in $15 \mathrm{ml}$ methanol to a solution of $\mathrm{K}_{2}\left[\mathrm{PdCl}_{2}\right](0.326 \mathrm{~g})$ in $15 \mathrm{ml}$ of water and stirring the solutions for one hour. For Imt complexes, mixing resulted in yellow (with 1:2 ratio) or dark brown color (with 1:4 ratio of Pd to Imt) solutions. In case of Mpy, reddish color, for Tna pale yellow color solutions, and for $\mathrm{Mpm}$ and 6-Mp, red color solutions were obtained. After filtration the solutions were kept at room temperature for three to five days. Solid products were obtained from water-methanol mixture on slow evaporation. The elemental analysis and melting points (m.p.) of the complexes are given in Table 1. 
Table 1

Elemental analysis, melting points and \% yield of palladium(II) complexes

\begin{tabular}{|c|c|c|c|c|c|c|}
\hline \multirow[t]{2}{*}{ Complexes } & \multicolumn{4}{|c|}{ Found (calculated) (\%) } & \multirow[t]{2}{*}{ m.p. $\left({ }^{\circ} \mathrm{C}\right)$} & \multirow[t]{2}{*}{ Yield (\%) } \\
\hline & $\mathrm{C}$ & $\mathrm{H}$ & $\mathrm{N}$ & $S$ & & \\
\hline$\overline{\left[\mathrm{Pd}(\operatorname{Imt})_{2} \mathrm{Cl}_{2}\right]^{*}}$ & $\begin{array}{c}22.21 \\
(18.88)\end{array}$ & $\begin{array}{c}3.81 \\
(3.17)\end{array}$ & $\begin{array}{c}17.06 \\
(14.68)\end{array}$ & $\begin{array}{c}19.25 \\
(16.83)\end{array}$ & 190 & 75 \\
\hline$\left[\mathrm{Pd}(\operatorname{Imt})_{4}\right] \mathrm{Cl}_{2}$ & $\begin{array}{c}24.38 \\
(24.60)\end{array}$ & $\begin{array}{c}4.34 \\
(4.13)\end{array}$ & $\begin{array}{c}18.73 \\
(19.12)\end{array}$ & $\begin{array}{c}22.27 \\
(21.80)\end{array}$ & 207 & 70 \\
\hline$\left[\mathrm{Pd}(\mathrm{Mpy})_{2} \mathrm{Cl}_{2}\right]$ & $\begin{array}{c}30.96 \\
(30.05)\end{array}$ & $\begin{array}{c}2.79 \\
(2.52)\end{array}$ & $\begin{array}{r}7.45 \\
(7.01)\end{array}$ & $\begin{array}{c}17.14 \\
(16.05)\end{array}$ & 284 & 70 \\
\hline$\left[\mathrm{Pd}(\mathrm{Mpy})_{4}\right] \mathrm{Cl}_{2}{ }^{*}$ & $\begin{array}{c}32.17 \\
(38.62)\end{array}$ & $\begin{array}{c}2.09 \\
(3.24)\end{array}$ & $\begin{array}{l}11.35 \\
(9.01)\end{array}$ & $\begin{array}{c}22.39 \\
(20.62)\end{array}$ & 260 & 75 \\
\hline$\left[\mathrm{Pd}(\mathrm{Mpm})_{4}\right] \mathrm{Cl}_{2}$ & $\begin{array}{c}29.98 \\
(30.70)\end{array}$ & $\begin{array}{c}2.56 \\
(2.58)\end{array}$ & $\begin{array}{c}15.99 \\
(17.90)\end{array}$ & $\begin{array}{c}18.37 \\
(20.49)\end{array}$ & 225 & 70 \\
\hline$\left[\mathrm{Pd}(6-\mathrm{Mp})_{2} \mathrm{Cl}_{2}\right]$ & $\begin{array}{c}26.71 \\
(24.93)\end{array}$ & $\begin{array}{c}2.43 \\
(1.67)\end{array}$ & $\begin{array}{c}24.36 \\
(23.26)\end{array}$ & $\begin{array}{c}13.88 \\
(13.31)\end{array}$ & 350 & 65 \\
\hline$\left[\mathrm{Pd}(\mathrm{Tna}) \mathrm{Cl}_{2}\right]^{* *}$ & $\begin{array}{c}23.00 \\
(22.82)\end{array}$ & $\begin{array}{c}2.62 \\
(1.91)\end{array}$ & $\begin{array}{c}8.02 \\
(8.87)\end{array}$ & $\begin{array}{c}13.25 \\
(10.16)\end{array}$ & 243 & 60 \\
\hline$\left[\mathrm{Pd}(\mathrm{Tna})_{2} \mathrm{Cl}_{2}\right]$ & $\begin{array}{c}28.17 \\
(31.77)\end{array}$ & $\begin{array}{c}2.78 \\
(2.67)\end{array}$ & $\begin{array}{c}11.10 \\
(12.35)\end{array}$ & $\begin{array}{c}12.58 \\
(14.14)\end{array}$ & 247 & 70 \\
\hline
\end{tabular}

${ }^{*}$ The analysis percentages of these complexes do not correspond to either composition, $\left[\mathrm{PdL}_{2} \mathrm{Cl}_{2}\right]$ or $\left[\mathrm{PdL}_{4}\right] \mathrm{Cl}_{2}$ and are in between the two calculated values. However, in case of $\left[\mathrm{Pd}(\mathrm{Mpy})_{4}\right] \mathrm{Cl}_{2}$ it is close to $\left[\mathrm{Pd}(\mathrm{Mpy})_{2} \mathrm{Cl}_{2}\right]$.

*** The complex $\left[\mathrm{Pd}(\mathrm{Tna}) \mathrm{Cl}_{2}\right]$ was prepared in the reaction with the ratio of 1:4.

\subsection{Measurements}

Elemental analysis was carried out on a Leco CHNS-932, Leco Corporation, USA. Melting point was recorded on an Electrothermal IA 9000 Series, Essex SS2 5PH, UK. FT-IR spectra were recorded on a Thermo Nicolet Nexus 6700, USA. The ${ }^{1} \mathrm{H}$ and ${ }^{13} \mathrm{C}$ NMR spectra of the ligands and their complexes in DMSO- $\mathrm{d}_{6}$ were obtained on Bruker Avance $300 \mathrm{MHz}$ NMR spectrometer operating at frequencies of 300.00 and $75.47 \mathrm{MHz}$ respectively at $300 \mathrm{~K}$. The spectral conditions were: $32 \mathrm{~K}$ data points, 1.822 $\mathrm{s}$ acquisition time, $2.00 \mathrm{~s}$ pulse delay and $6.00 \mu \mathrm{s}$ pulse width. The ${ }^{13} \mathrm{C}$ chemical shifts were measured relative to TMS.

\subsection{Antibacterial activities of the complexes}

The antibacterial activity of all synthesized metal complexes has been investigated against four bacteria, two G(+) i.e. Staphylococcus aureus ATCC 25923, Bacillus subtilis DSM 3256 (Germany), and two G(-) bacterial strains i.e. Escherichia coli ATCC 25922 and Pseudomonas aeruginosa ATCC 10197 by the agar well diffusion method [51-53]. Imipenum was used as standard antibiotic, which is $\beta$-Lactam antibiotic effective against $\mathrm{G}(+)$ as well as $\mathrm{G}(-)$ bacteria. $3 \mathrm{mg}$ of the test samples (ligands and complexes) were dissolved in $1 \mathrm{ml}$ of DMSO. 2-3 ml nutrient broth $(0.8 \mathrm{~g} / 100 \mathrm{ml})$ was prepared in distilled water with $\mathrm{pH} 7$ and was autoclaved at $121^{\circ} \mathrm{C}, 15 \mathrm{psi}$ pressure and for $20 \mathrm{~min}$. Fresh culture grown in $24 \mathrm{~h}$ on nutrient broth at $\mathrm{pH} 7$ were used for sensitivity testing. To compare the turbidity of bacterial cultures $\mathrm{McF}$ arland $\mathrm{BaSO}_{4}$ solution was used as turbidity standard. To perform antibacterial assay, nutrient agar medium was prepared by dissolving $2 \mathrm{~g} / 100 \mathrm{ml}$ in distilled water with $\mathrm{pH} 7$ and the medium 
was autoclaved. A $25 \mathrm{ml}$ of the nutrient agar medium was poured in Petri plates of $9 \mathrm{~cm}$ diameter and allowed to solidify. Using sterile cotton swabs lawns of test cultures were prepared on labeled plates. Four wells per plate were prepared with the help of sterile cork borer $(2 \mathrm{~mm})$. Using micropipette, $30 \mu \mathrm{l}$ of test solution were poured in respective labeled wells. Now, these Experimental plates were incubated for $24 \mathrm{~h}$ and average of zones of inhibition (\%) of three replicates were measured and compared with the zone of standard antibiotic imipenum with zone inhibition of 21, 18, 16 and $18 \mathrm{~mm}$ respectively, which were taken as $100 \%$ (Table 4).

\section{Results and discussion}

\subsection{IR studies}

The palladium(II) complexes of the types, $\left[\mathrm{Pd}\right.$ (thione) $\left.{ }_{2} \mathrm{Cl}_{2}\right]$ and $\left.[\mathrm{Pd} \text { (thione) })_{4}\right] \mathrm{Cl}_{2}$ were obtained from reaction of $\mathrm{K}_{2}\left[\mathrm{PdCl}_{2}\right]$ with thiones in 1:1 and 1:2 molar in methanol-water media. However, the elemental analysis suggests that only in case of Imt and Mpy, both types of products were formed. For Mpm only $\left[\mathrm{Pd}(\text { thione })_{4}\right] \mathrm{Cl}_{2}$ type, while for 6-Mp, only $\left[\mathrm{Pd}(\text { thione })_{2} \mathrm{Cl}_{2}\right]$ type complexes were obtained. In the reactions of Tna, the analysis shows that the complex of the type [Pd(thione) $\left.\mathrm{Cl}_{2}\right]$ was also formed. Selected IR spectroscopic vibrational bands for the free ligands and their palladium(II) complexes are given in Table 2. In the IR spectrum of thiones, the characteristic bands are observed in three frequency regions; $\nu(\mathrm{C}=\mathrm{S})$ appears around $600 \mathrm{~cm}^{-1}, \nu(\mathrm{C}-\mathrm{N})$ at about $1500 \mathrm{~cm}^{-1}$ and $\nu(\mathrm{N}-\mathrm{H})$ is observed near $3200 \mathrm{~cm}^{-1}$. The presence of $\mathrm{N}-\mathrm{H}$ vibrations in the complexes confirms the thione forms of the ligands in the solid state. The $\delta(\mathrm{N}-\mathrm{H})$ bands were observed at $1675-1515 \mathrm{~cm}^{-1}$. The absorptions at $366-320 \mathrm{~cm}^{-1}$ and at $302-270 \mathrm{~cm}^{-1}$ were attributed to $\nu(\mathrm{Pd}-\mathrm{S})$ and $\nu(\mathrm{Pd}-\mathrm{Cl})$ vibrations respectively [54].

\subsection{NMR studies}

In ${ }^{1} \mathrm{H}$ NMR spectra of the complexes the $\mathrm{N}-\mathrm{H}$ signal of thiones become less intense upon coordination and shifted slightly downfield with respect to their positions in free ligands. However, it could not be

Table 2

Selected IR absorption $\left(\mathrm{cm}^{-1}\right)$ for free ligands and their palladium(II) complexes

\begin{tabular}{lcccccc}
\hline Species & $\nu(\mathrm{C}=\mathrm{S})$ & $\nu(\mathrm{N}-\mathrm{H})$ & $\delta(\mathrm{N}-\mathrm{H})$ & $\nu(\mathrm{C}-\mathrm{N})$ & $\nu(\mathrm{Pd}-\mathrm{S})$ & $\nu(\mathrm{Pd}-\mathrm{Cl})$ \\
\hline $\mathrm{Imt}$ & 510 & 3237 & 1515 & 1454 & - & - \\
{$\left[\mathrm{Pd}(\mathrm{Imt})_{2} \mathrm{Cl}_{2}\right]$} & 497 & 3362 & - & 1476 & 326 & 280 \\
{$\left[\mathrm{Pd}(\mathrm{Imt})_{4}\right] \mathrm{Cl}_{2}$} & 526 & 3419,3318 & 1617 & 1435 & 329 & 282 \\
$\mathrm{Mpy}$ & 613 & 3176 & 1578 & 1487 & - & - \\
{$\left[\mathrm{Pd}(\mathrm{Mpy})_{2} \mathrm{Cl}_{2}\right]$} & 590 & 3179 & 1567 & 1485 & 343 & 291 \\
{$\left[\mathrm{Pd}(\mathrm{Mpy})_{4}\right] \mathrm{Cl}_{2}$} & 546 & 3180 & 1571 & 1490 & 345 & 292,268 \\
$\mathrm{Mpm}$ & 624 & 3053 & 1602 & 1491 & - & - \\
{$\left[\mathrm{Pd}(\mathrm{Mpm})_{4}\right] \mathrm{Cl}_{2}$} & 630 & 3070 & 1548 & 1466 & 354 & 291 \\
$6-\mathrm{Mp}$ & 588 & 3431 & 1614 & 1576 & - & - \\
{$\left[\mathrm{Pd}\left(6-\mathrm{Mp}_{2} \mathrm{Cl}_{2}\right]\right.$} & 626 & 3398 & 1626 & - & 366 & 302 \\
$\mathrm{Tna}$ & 698 & 3180 & 1675 & 1468 & - & - \\
{$\left[\mathrm{Pd}(\mathrm{Tna}) \mathrm{Cl}_{2}\right]$} & 695 & 3230 & 1674 & 1405 & 302 & 273 \\
{$\left[\mathrm{Pd}(\mathrm{Tna})_{2} \mathrm{Cl}_{2}\right]$} & 669 & - & 1674 & 1406 & 325 & 273 \\
\hline
\end{tabular}


observed in all cases. The deshielding of the $\mathrm{N}-\mathrm{H}$ proton is related to an increase of the $\pi$ electron density in the $\mathrm{C}-\mathrm{N}$ bond upon complexation [22]. A slight downfield shift was also observed in the $\mathrm{C}-\mathrm{N}$ and aromatic protons. For example, in $\left[\mathrm{Pd}(\mathrm{Mpy})_{2} \mathrm{Cl}_{2}\right]$ the aromatic protons at $\mathrm{C}-3, \mathrm{C}-4, \mathrm{C}-5$ and $\mathrm{C}-\mathrm{N}$ appear at 7.78, 7.20, 7.65, $7.94 \mathrm{ppm}$ respectively (for the free ligand; 7.338, 6.808, 7.467 and 7.705 ppm). The protons at $\mathrm{C}-3$ and $\mathrm{C}-\mathrm{N}$ appear as doublets, while the other two appear as triplets. In 6-MP, the $\mathrm{H}-2$ and H-8 protons appear at 8.20 and $8.40 \mathrm{ppm}$ respectively [13]. Palladium complexation causes a downfield shift of about 0.3 ppm H-8 proton and the signal is also broadened, while the H-2 proton is only slightly shifted. The shift in $\mathrm{H}-8$ suggests the involvement of N-7 in binding to metal ion $\left(\mathrm{Pd}^{2+}\right)$. In the ${ }^{1} \mathrm{H} \mathrm{NMR}$ spectrum of Mpm, two signals were observed, a triplet at $6.90 \mathrm{ppm}$ and a broad signal at $8.33 \mathrm{ppm}$. On coordination the signal at $6.90 \mathrm{ppm}$ was shifted to $7.07 \mathrm{ppm}$, while the one at $8.33 \mathrm{ppm}$ split into two resonances, 8.31 and $8.92 \mathrm{ppm}$. All three signals appeared as quartets.

The ${ }^{13} \mathrm{C}$ NMR chemical shifts of the ligands and their complexes are given in Table 3. Upfield shifts are observed in the $>\mathrm{C}=\mathrm{S}$ resonance of the ligands on their complexation with palladium(II). The upfield is attributed to the lowering of $>\mathrm{C}=\mathrm{S}$ bond of $\mathrm{N} \rightarrow \mathrm{C}$ electron density producing a partial double bond character in the $\mathrm{C}-\mathrm{N}$ bond, as observed in the other palladium(II) complexes of thiones $[34,55]$. However, in case of 6-MP complexes instead of an upfield, a downfield shift was observed in the $>C=S$ resonance. This observation is consistent with the other reported studies [13,28]. Also in the 6-Mp complex, the C-5 and C-8 signals split into two resonances, showing that 6-Mp forms two geometrical isomers with palladium(II). A similar observation has been made for a gold complex [56]. Significantly large shifts in these two resonances indicate that N-7 nitrogen is involved in metal binding. As the shift difference may be related to the strength of metal-sulfur bond, Table 3 suggests that the Tnm complex with the most significant shift in the $\mathrm{C}=\mathrm{S}$ resonance would be the most stable.

\subsection{Antibacterial studies}

The antibacterial activities of $\mathrm{Pd}(\mathrm{II})$ complexes have been determined against four strains of bacteria (Staphylococcus aureus (ATCC 25923), Bacillus subtilis (DSM 3256), Escherichia coli (ATCC 25922)

Table 3

${ }^{1} \mathrm{H}$ and ${ }^{13} \mathrm{C}$ chemical shifts of heterocyclic thiones and their palladium(II) complexes in DMSO-d 6

\begin{tabular}{lccccccc}
\hline Species & $\mathrm{N}-\mathrm{H}$ & $\mathrm{C}-2$ & $\mathrm{C}-3$ & $\mathrm{C}-4$ & $\mathrm{C}-5$ & $\mathrm{C}-6$ & $\mathrm{C}-7 / \mathrm{C}-8$ \\
\hline $\mathrm{Imt}$ & 7.99 & 183.86 & - & 44.40 & 44.40 & - & - \\
{$\left[\mathrm{Pd}(\mathrm{Imt})_{2} \mathrm{Cl}_{2}\right]$} & 8.82 & 178.22 & - & 45.46 & 45.46 & - & - \\
{$\left[\mathrm{Pd}(\mathrm{Imt})_{4}\right] \mathrm{Cl}_{2}$} & 8.26 & $177.22,176.79$ & - & $46.80,46.33$ & $46.80,46.33$ & - & - \\
$\mathrm{MPy}$ & - & 177.69 & 133.22 & 113.94 & 137.49 & 137.91 & - \\
{$\left[\mathrm{Pd}(\mathrm{Mpy})_{2} \mathrm{Cl}_{2}\right]$} & - & 157.79 & 122.29 & 120.03 & 138.64 & 150.19 & - \\
{$\left[\mathrm{Pd}(\mathrm{Mpy})_{4}\right] \mathrm{Cl}_{2}$} & - & 167.02 & 132.11 & 118.93 & 140.00 & 141.06 & - \\
$\mathrm{Mpm}$ & - & 181.90 & - & 155.00 & 109.96 & 155.00 & - \\
{$\left[\mathrm{Pd}(\mathrm{Mpm})_{4}\right] \mathrm{Cl}_{2}$} & - & 180.87 & - & 157.11 & 115.86 & 159.55 & - \\
$6-\mathrm{Mp}$ & - & 144.55 & - & 150.95 & 128.75 & 171.25 & 145.08 \\
{$\left[\mathrm{Pd}(6-\mathrm{Mp})_{2} \mathrm{Cl}_{2}\right]$} & 9.23 & 148.40 & - & 156.36 & $119.95,116.45$ & 174.13 & $128.54,131.09$ \\
$\operatorname{Tna}$ & $9.77,10.12$ & 151.59 & 135.31 & 134.87 & 123.06 & 147.61 & 197.92 \\
{$\left[\operatorname{Pd}(\mathrm{Tna})_{2} \mathrm{Cl}_{2}\right]$} & - & 154.56 & 138.00 & 136.16 & 126.50 & 149.35 & 178.08 \\
\hline
\end{tabular}

Note: NMR spectra of $\left[\mathrm{Pd}(\mathrm{Tna}) \mathrm{Cl}_{2}\right]$ could not be recorded because it did not dissolve in any solvent. It was only partially dissolved in DMSO on boiling but we were failed to analyze it. 
Table 4

Antibacterial activities of palladium(II) complexes of heterocyclic thiones

\begin{tabular}{|c|c|c|c|c|}
\hline \multicolumn{5}{|c|}{ Microorganism (\% zone of inhibition of Std. drugs, ligands and complexes) } \\
\hline $\begin{array}{l}\text { Name of } \\
\text { complex/ligand/Std. }\end{array}$ & $\begin{array}{c}\text { Staphylococcus } \\
\text { aureus } \\
\text { ATCC } 25923\end{array}$ & $\begin{array}{c}\text { Bacillus } \\
\text { subtilis } \\
\text { DSM } 3256\end{array}$ & $\begin{array}{c}\text { Escherichia } \\
\text { coli } \\
\text { ATCC } 25922\end{array}$ & $\begin{array}{c}\text { Pseudomonas } \\
\text { aeruginosa } \\
\text { ATCC } 10197\end{array}$ \\
\hline & \multicolumn{4}{|c|}{$\%$ value } \\
\hline Imipenum & $100(21 \mathrm{~mm})^{*}$ & $100(18 \mathrm{~mm})^{*}$ & $100(16 \mathrm{~mm})^{*}$ & $100(18 \mathrm{~mm})^{*}$ \\
\hline Imt & 0 & 22 & 38 & 28 \\
\hline$\left[\mathrm{Pd}(\operatorname{Imt})_{2} \mathrm{Cl}_{2}\right]$ & 19 & 45 & 25 & 28 \\
\hline$\left[\mathrm{Pd}(\operatorname{Imt})_{4}\right] \mathrm{Cl}_{2}$ & 10 & 11 & 13 & 11 \\
\hline Mpy & 52 & 95 & 100 & 83 \\
\hline$\left[\mathrm{Pd}(\mathrm{Mpy})_{2} \mathrm{Cl}_{2}\right]$ & 48 & 28 & 69 & 39 \\
\hline$\left[\mathrm{Pd}(\mathrm{Mpy})_{4}\right] \mathrm{Cl}_{2}$ & 19 & 28 & 38 & 28 \\
\hline $\mathrm{Mpm}$ & 19 & 45 & 63 & 45 \\
\hline$\left[\mathrm{Pd}(\mathrm{Mpm})_{4}\right] \mathrm{Cl}_{2}$ & 48 & 33 & 13 & 17 \\
\hline 6-Mp & 10 & 17 & 13 & 11 \\
\hline$\left[\mathrm{Pd}(6-\mathrm{Mp})_{2}\right] \mathrm{Cl}_{2}$ & 0 & 0 & 0 & 11 \\
\hline Tna & 0 & 0 & 18.7 & 0 \\
\hline$\left[\mathrm{Pd}(\mathrm{Tna})_{2} \mathrm{Cl}_{2}\right]$ & 10 & 11 & 0 & 17 \\
\hline
\end{tabular}

*Percentage corresponding to zone of inhibition.

and Pseudomonas aeruginosa (ATCC 10197). The results (average of three measurements) shown in Table 4 suggest that the complexes exhibit a wide range of activities against these bacteria. The mercaptopyridine complex, $\left[\mathrm{Pd}(\mathrm{Mpy})_{2} \mathrm{Cl}_{2}\right]$ exhibits the most significant activity among these complexes especially, its activity against Escherichia coli is remarkable. However, the activity of mercaptopyridine as a free ligand is even more pronounced. Similarly, uncomplexed mercaptopyrimidine also shows greater activity than the complexes. The complexes of mercaptopyrimidine, and imidazolidine-2-thione exhibited a moderate activity against all of these bacteria. The 6-mercatopurine complex is only effective against Pseudomonas aeruginosa and inactive against all others. Thionicotinamide complex is effective against all three bacteria and inactive against Escherichia coli.

The antibacterial activities of the complexes are due to a direct interaction of metal ions with biological ligands such as proteins, enzymes and membranes [57-59]. The antibacterial activity of $\mathrm{Pd}(\mathrm{II})$ complexes may be attributed to their tendency to undergo further ligand replacement reactions with the biological ligands such as proteins and DNA. The greater activity of mercaptopyridine and mercaptopyrimidine complexes is possibly because of the formation of a strained 4-membered ring due to which $\mathrm{Pd}(\mathrm{II})$ becomes more labile in these complexes. In case of 6-mercatopurine and thionicotinamide, a stable chelate is formed due to which the ligands could not be displaced easily by biological ligands and as a result the activities are poor.

The present study shows that thiones can form complexes with palladium(II) with different M:L ratios in which the ligands exist in the thione form. One of the complexes exhibits significant biological activity showing the potential for its use as antibacterial agent. It has been observed that antibacterial activity decreases on complexation, while some ligands are biologically inactive but upon coordination showed biological activity. The inactivity or decreased biological activity of some of the complexes may be related to the strongly coordinated ligands with the metal [59]. 


\section{References}

[1] E.S. Raper, Coord. Chem. Rev. 61 (1985), 115-184.

[2] E.S. Raper, Coord. Chem. Rev. 129 (1994), 91-156.

[3] E.S. Raper, Coord. Chem. Rev. 153 (1996), 199-255.

[4] P.D. Akrivos, Coord. Chem. Rev. 213 (2001), 181-210.

[5] W. Kaim and B. Schwederski, Bioinorganic Chemistry: Inorganic Elements in the Chemistry of Life, John Wiley and Sons Inc., New York, 1994.

[6] H. Fleischer, Coord. Chem. Rev. 249 (2005), 799-827.

[7] R. del Campo, J.J. Criado, R. Gheorghe, F.J. González, M.R. Hermosa, F. Sanz, J.L. Manzano, E. Monte and E. RodríguezFernández, J. Inorg. Biochem. 98 (2004), 1307-1314.

[8] E. Rodríguez-Fernández, J.L. Manzano, J.J. Benito, R. Hermosa, E. Monte and J.J. Criado, J. Inorg. Biochem. 99 (2005), $1558-1572$.

[9] G. Marverti, M. Cusumano, A. Ligabue, M.L. Di Pietro, P.A. Vainiglia, A. Ferrari, M. Bergomi, M.S. Moruzzi and C. Frassineti, J. Inorg. Biochem. 102 (2008), 699-712.

[10] P.M. Krishna, K.H. Reddy, J.P. Pandey and D. Siddavattam, Transition Met. Chem. 33 (2008), 661-668.

[11] S. Krischner, Y.-K. Wei, D. Francis and J.G. Bergman, J. Med. Chem. 9 (1966), 369-372.

[12] N. Hadjiliadis and T. Theophanides, Inorg. Chim. Acta 15 (1975), 167-178.

[13] L. Iwona, P. Leszek, S. Jerzy, K. Lech, P. Marzena, N. Anna, O. Adam and S. Edward, J. Mol. Struct. 707 (2004), $241-247$.

[14] F.B. Stocker, M.A. Troester and D. Britton, Inorg. Chem. 35 (1996), 3145-3153.

[15] T.S. Lobana, S. Khanna, R.J. Butcher, A.D. Hunter and M. Zeller, Polyhedron 25 (2006), 2755-2763.

[16] P. Zoufalá, T. Rüffer, H. Lang, S. Ahmad and M. Mufakkar, Anal. Sci.: X-Ray Struct. Anal. Online 23 (2007), x219-x220.

[17] M. Mufakkar, S. Ahmad, I.U. Khan, H.K. Fun and S. Chantrapromma, Acta Crystallogr. E63 (2007), m2384.

[18] A.A. Isab, S. Ahmad and M. Arab, Polyhedron 21 (2002), 1267-1271.

[19] W. Ashraf, S. Ahmad and A.A. Isab, Transition Met. Chem. 29 (2004), 400-404.

[20] M. Hanif, S. Ahmad, M. Altaf and H. Stoeckli-Evans, Acta Crystallogr. E63 (2007), m2594.

[21] F.B. Stocker, D. Britton and V.G. Young, Inorg. Chem. 39 (2000), 3479-3484.

[22] C. Pakawatchai, K. Sivakumar and H.K. Fun, Acta Crystallogr. C52 (1996), 1954-1957.

[23] H.K. Fun, I.A. Razak, C. Pakawatchai, S. Chantrapromma and S. Saithong, Acta Crystallogr. C54 (1998), $453-456$.

[24] J.S. Casas, E.G. Martinez, A. Sanchez, A.S. Gonzalez, J. Sordo, U. Casellato and R. Graziani, Inorg. Chim. Acta 241 (1996), 117-123.

[25] F.B. Stocker and D. Britton, Acta Crystallogr. C56 (2000), 798-800.

[26] S. Ahmad, A.A. Isab and H.P. Perzanowski, Can. J. Chem. 80 (2002), 1279-1284.

[27] A.A. Isab, M.B. Fettouhi, S. Ahmad and L. Ouahab, Polyhedron 22 (2003), 1349-1354.

[28] B. Fischer, E. Dubler, M. Meienberger and K. Hegetschweiler, Inorg. Chim. Acta 279 (1998), 136-143.

[29] S.S. Kandil, S.M.A. Katib and N.H.M. Yarkandi, Transition Met. Chem. 32 (2007), 791-798.

[30] W. Henderson, L.J. McCaffrey and B.K. Nicholson, J. Chem. Soc., Dalton Trans. (2000), 2753-2760.

[31] A.P. Rebolledo, M. Vieites, D. Gambino, O.E. Piro, E.E. Castellano, C.L. Zani, E.M. Souza-Fagundes, L.R. Teixeira, A.A. Batista and H. Beraldo, J. Inorg. Biochem. 99 (2005), 698-706.

[32] A.I. Matesanz and P. Souza, J. Inorg. Biochem. 101 (2007), 1354-1361.

[33] S. Nadeem, M.K. Rauf, M. Ebihara, S.A. Tirmizi and S. Ahmad, Acta Crystallogr. E64 (2008), m698-m699.

[34] S. Nadeem, M.K. Rauf, S. Ahmad, M. Ebihara, S.A. Tirmizi, S.A. Bashir and A. Badshah, Transition Met. Chem. 34 (2009), 197-202.

[35] Z. Atherton, D.M.L. Goodgame, S. Menzer and D.J. Williams, Inorg. Chem. 37 (1998), 849-858.

[36] M. Fettouhi, M.I.M. Wazeer and A.A. Isab, Z. Kristallogr. NCS 221 (2006), 221-222.

[37] M. Fettouhi, M.I.M. Wazeer and A.A. Isab, J. Coord. Chem. 60 (2007), 369-377.

[38] V.Z. Vassileva and P.P. Petrova, Croatica Chim. Acta 78 (2005), 295-299.

[39] A. Beheshti, W. Clegg, S.H. Dale and R. Hyvadi, Inorg. Chim. Acta 360 (2007), 2967-2972.

[40] M.I.M. Wazeer, A.A. Isab and M. Fettouhi, Polyhedron 26 (2007), 1725-1730.

[41] S. Ali, M.R. Malik, A.A. Isab and S. Ahmad, J. Coord. Chem. 62 (2009), 475-480.

[42] U. Rajalingam, P.W.A. Dean, H.A. Jenkins, M. Jennings and J.M. Hook, Can. J. Chem. 79 (2001), 1330-1337.

[43] N.A. Bell, W. Clegg, S.J. Coles, C.P. Constable, R.W. Harrington, M.B. Hursthouse, M.E. Light, E.S. Raper, C. Sammon and M.R. Walker, Inorg. Chim. Acta 357 (2004), 2091-2099.

[44] M.J. Moloto, M.A. Malik, P. O'Brien, M. Motevalli and G.A. Kolawole, Polyhedron 22 (2003), 595-603.

[45] A. Tadjarodi, F. Adhami and Z. Gharehdaghi, Anal. Sci.: X-Ray Struct. Anal. Online 23 (2007), x35-x36.

[46] E.S. Raper, J.R. Creighton, N.A. Bell, W. Clegg and L. Cucurull-Sanchez, Inorg. Chim. Acta 277 (1998), 14-20.

[47] Z. Popovic, G. Pavlovic, D. Matkovic-Calogovic, Z. Soldin, M. Rajic, D. Vikic-Topic and D. Kovacek, Inorg. Chim. Acta 306 (2000), 142-152. 
[48] N.A. Bell, T.N. Branston, W. Clegg, J.R. Creighton, L. Cucurull-Sánchez, M.R.J. Elsegood and E.S. Raper, Inorg. Chim. Acta 303 (2000), 220-227.

[49] Z. Popovic, Z. Soldin, D. Matkovic-Calogovic, G. Pavlovic, M. Rajic and G. Giester, Eur. J. Inorg. Chem. (2002), 171180.

[50] M.I.M. Wazeer and A.A. Isab, Spectrochim. Acta A68 (2007), 1207-1212.

[51] T.K. Mohanta, J.K. Patra, S.K. Rath, D.K. Pal and H.N. Thatoi, Sci. Res. Essays 2 (2007), 486-490.

[52] S.U. Kazmi, S.N. Ali, S.A. Jamal and Atta-ur-Rehamn, Pak. J. Pharm. Sci. 4 (1991), 113-123.

[53] S.S. Shaukat, N.A. Khan and F. Ahmad, Pak. J. Bot. 12 (1980), 97-106.

[54] J. Jolley, W.I. Cross, R.G. Pritchard, C.A. McAuliffe and K.B. Nolan, Inorg. Chim. Acta 315 (2001), 36-43.

[55] A.A. Isab, A.R. Al-Arfaj, M. Arab and M.M. Hassan, Transition Met. Chem. 19 (1994), 87-90.

[56] S. Ahmad and A.A. Isab, J. Coord. Chem. 55 (2002), 189-203.

[57] R.P. John, A. Sreekanth, V. Rajakannan, T.A. Ajith and M.R.P. Kurup, Polyhedron 23 (2004), 2549-2559.

[58] M. Hanif, A. Saddiqa, S. Hasnain, S. Ahmed, G. Rabbani and A.A. Isab, Spectroscopy 22 (2008), 51-56.

[59] S. Ahmad, A.A. Isab, S. Ali and A.R. Al-Arfaj, Polyhedron 25 (2006), 1633-1645. 


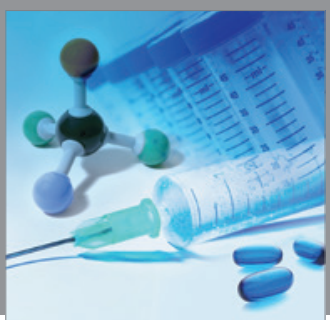

International Journal of

Medicinal Chemistry

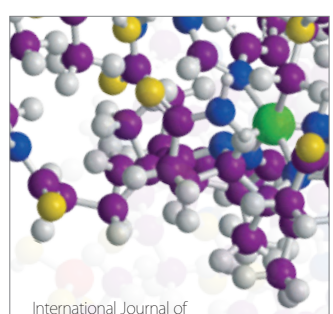

Carbohydrate Chemistry

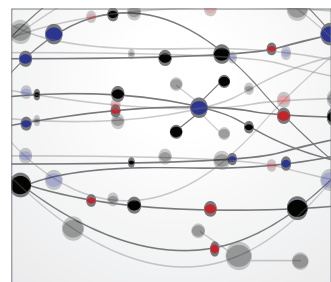

The Scientific World Journal
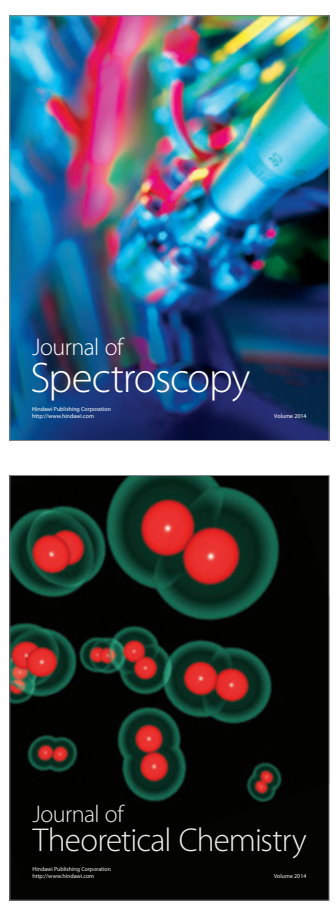
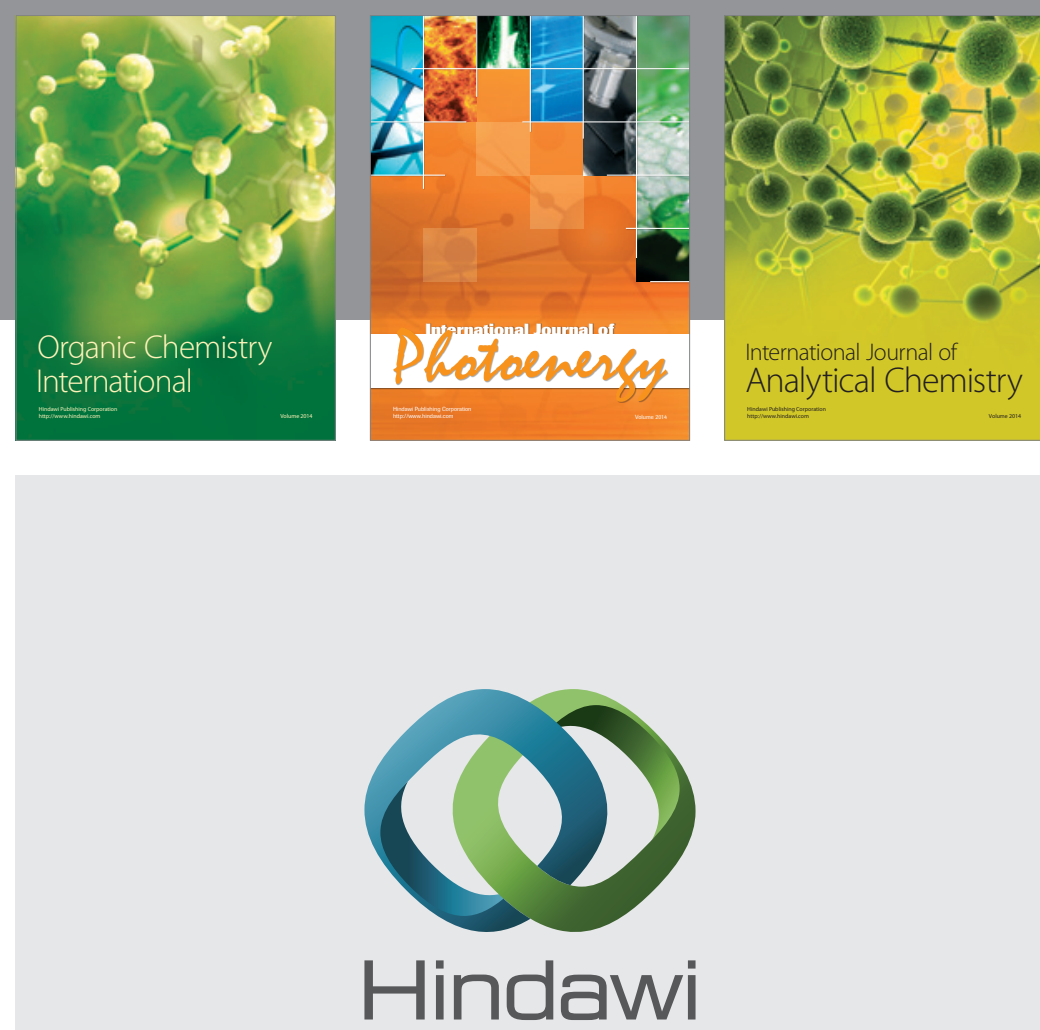

Submit your manuscripts at

http://www.hindawi.com
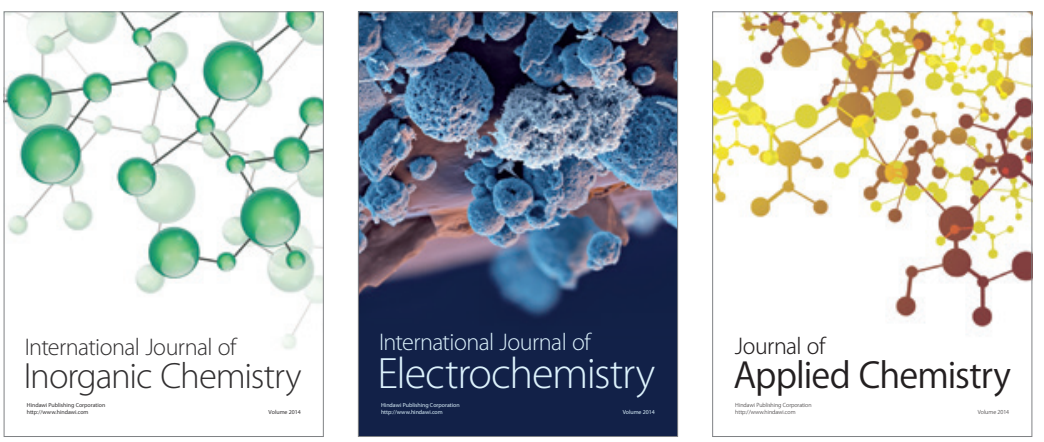

Journal of

Applied Chemistry
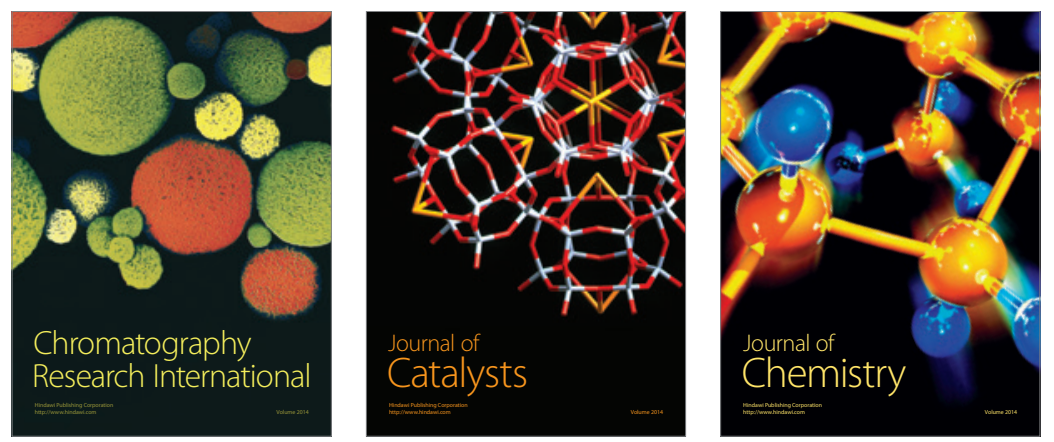
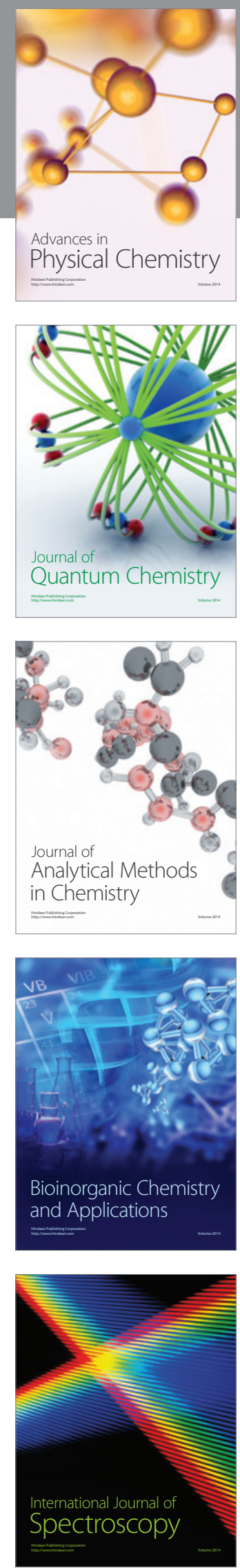